\title{
Fecal microbiota transplantation via colonoscopy in a dog with Clostridioides (Clostridium) difficile infection
}

\author{
Amanda Nadia Diniz ${ }^{1}$ (i) Angélica da Costa Ferreira de Souza ${ }^{1}$ (i) \\ Anelise Carvalho Nepomuceno ${ }^{1}$ (i) Sóstenes Apolo Correia Marcelino ${ }^{1}$ (D) Felipe Pierezan $^{1}$ (I) \\ Francisco Carlos Faria Lobato ${ }^{1}$ (D) Rodrigo Otávio Silveira Silva ${ }^{*}$ (D)
}

${ }^{1}$ Escola de Veterinária. Universidade Federal de Minas Gerais (UFMG), 31270-901, Belo Horizonte, MG, Brasil. E-mail: rodrigo.otaviosilva@gmail.com. ${ }^{*}$ Corresponding author.

ABSTRACT: In dogs, antimicrobial therapy for Clostridioides (Clostridium) difficile infection (CDI) is based solely on metronidazole, leaving limited treatment options in case of recurrent disease. Fecal microbiota transplantation (FMT) has been successfully used in humans with recurrent CDI, whereas the usefulness of this approach is largely unknown in dogs. In the present study, a dog with a chronic-recurring diarrhea was treated with FMT via colonoscopy. CDI was confirmed by A/B toxin detection and isolation of toxigenic C. difficile from ribotype 106, a strain also commonly associated with nosocomial infection in humans. The dog recovered well after the procedure and C. difficile was no longer isolated from its stool sample. The present research suggested that FMT could be a useful tool to treat recurrent CDI in dogs, corroborating the actual protocol in humans.

Key words: canine diarrhea, FMT, colitis.

Transplante de microbiota fecal via colonoscopia em um cão com infecção por Clostridioides (Clostridium) difficile

\begin{abstract}
RESUMO: Em cães, a terapia antimicrobiana para infecções por Clostridioides (Clostridium) difficile é baseada apenas no uso de metronidazol, limitando as opções de tratamento nos casos de recorrência. O transplante de microbiota fecal (FMT) tem sido utilizado com sucesso em seres humanos com infecções recorrentes por $C$. difficile, porém a utilidade desse método é ainda amplamente desconhecida em cães. O presente trabalho relata a utilização de FMT para o tratamento de um cão com diarreia crônica-recorrente por $C$. difficile. A infecção foi confirmada por detecção das toxinas $A / B$ e isolamento de uma estirpe toxigênica do ribotipo 106, linhagem comumente associada a infecção em seres humanos. Após o transplante via colonoscopia, o animal se recuperou do quadro e C. difficile não mais foi encontrado em novas amostras fecais. O presente trabalho sugere que o FMT possa ser útil para o tratamento de quadros de C. difficile em cães, corroborando protocolo atual de tratamento em seres humanos.

Palavras-chave: diarreia, FMT, colite.
\end{abstract}

Clostridioides (Clostridium) difficile infection (CCD) is the main cause of nosocomial diarrhea in humans (DE ROO et al., 2020). In dogs, it has been identified as the etiological agent of 10 $21 \%$ of cases of diarrhea worldwide with clinical signs varying from chronic-recurring to bloody lifethreatening diarrhea (WETTERWIK et al., 2013; DINIZ et al. 2018). Studies have suggested that CDI can occur in dogs as a primary disease (DINIZ et al., 2018) or secondary due to allergic or inflammatory gut disease or even in association with other enteropathogens (SILVA et al., 2017; DINIZ et al., 2018; SILVA et al. 2018).
In addition to its possible role as an enteropathogen in dogs, $C$. difficile isolates from dogs have a high genetic similarity with those recovered from infected humans, raising the possibility of a zoonotic disease with animals playing a role in increasing cases of community acquired CDI in humans (RODRIGUEZ et al. 2016; WEESE et al. 2020).

The treatment of CDI in humans is mostly based on antimicrobial therapy with metronidazole, vancomycin or, less frequently, fidaxomicin (ASLAM et al., 2005). Regardless of which antimicrobial is used, 10 to $30 \%$ of the patients have a recurrence of the infection, which is partially due to the inability 
of their microbiota to quickly recover and prevent a new CDI episode. In these cases, fecal microbiota transplantation (FMT), or the "transfer of intestinal contents from a healthy donor to a diseased recipient", has been successfully used in humans (BORODY \& KHORUTS, 2011; CHAITMAN et al. 2020). In dogs, antimicrobial therapy for CDI is based solely on metronidazole (MARKS et al., 2011). Interestingly, among the three main antimicrobials used for CDI in humans, metronidazole has the lowest cure rates (DI XIUZHEN et al., 2015). Despite the limited options for treatment of infected dogs, there are only two reports of oral FMT for treatment of CDI in animals: one in a dog (SUGITA et al., 2019) and another in a marmoset (YAMAZAKI et al., 2017). In the present research, we described, for the first time, a successful FMT via colonoscopy in a dog with chronic-recurring diarrhea associated with CDI.

In March 2018, a 4-year old female Golden Retriever was referred to the Veterinary Hospital of Federal University of Minas Gerais for consultation. The owner reported that the dog had been having chronic-recurring pasty large bowel diarrhea of two months duration. The dog had previously presented to two other clinics and the owners confirmed the historical use of metronidazole and amoxicillin with clavulanic acid. Deworming and vaccinations were up to date, the dog was fed with a homemade raw meat-based diet, and clinical examination revealed the animal was underweight but otherwise in good condition. Results of a complete blood count (CBC) and a serum biochemical analysis were normal.

To investigate an infectious cause of diarrhea, a stool sample was collected and submitted for evaluation of several enteropathogens. Commercial immunochromatographic tests were used to test for parvovirus (Alere, USA), rotavirus and coronavirus (Ecodiagnostica, Brazil) similar to previous studies (DINIZ et al., 2018). The presence of Giardia sp. was evaluated using a commercial enzyme immunoassay (RIDASCREEN ${ }^{\circledR}$ Giardia R-Biopharm AG). Clostridium perfringens isolation was conducted as previously described (MEER \& SONGER, 1997; SILVA et al., 2015) followed by the detection of the NetB-, NetE-, NetF and NetGencoding genes (KEYBURN et al., 2008; GOHARI et al., 2015). For diagnosis of CDI, the stool sample was first subjected to immunochromatographic tests for detection of the $C$. difficile glutamate dehydrogenase (GDH). Samples with a positive result were then subjected to a previous described isolation protocol used to evaluate for the presence of C. difficile (SILVA et al., 2013). Colonies underwent
PCR for a housekeeping gene (tpi), toxins A $(t c d A)$ and $\mathrm{B}(t c d B)$, and a binary toxin gene $(c d t B)$ (SILVA et al., 2011). The stool sample was also subjected to A/B toxin detection (C. difficile Tox A/B II - Techlab Inc., Blacksburg, VA, USA).

For E. coli isolation, stool samples were plated on MacConkey agar (Difco, USA). Up to three lactose-fermenting colonies were identified by PCR (MCDANIELS et al., 1996) and virulence genes associated with diarrhea were investigated as previously described (FRANCK et al., 1998; YAMAMOtO et al., 1997; GUNZBURG et al.,1995; TOKUDA et al., 2010). For the isolation of Salmonella spp., the stool sample was inoculated in Rappaport-Vassiliadis Broth (Oxoid, USA) followed by plating in Hektoen Agar (Oxoid, USA). Suggestive colonies (sulfite-reducing colonies) were submitted to PCR analysis (KWANG et al., 1996). The fecal flotation method was used for detection of nematode and cestode eggs (DE SANTIS et al., 2006).

The stool sample was positive for A/B toxins, and a toxigenic $C$. difficile strain was isolated confirming CDI in the patient. No other enteropathogens were detected. A recent study in our institution had already diagnosed CDI in dogs with chronic recurring diarrhea (SILVA et al., 2018). Interestingly, those animals were later diagnosed with alimentary allergies, suggesting that CDI was secondary to the dysbiosis caused by the associated inflammation of the intestines. Considering this possibility, the owner agreed to present the dog from the present study for a colonoscopy. The macroscopic findings suggested mild colitis-characterized by hyperemic areas in the ileocolic and cecocolic sphincters in the descending colon and in the rectum. In this last intestinal segment, a moderate amount of whitish fibrin filaments was observed. Samples of mucosa biopsies from the ascending colon, transverse colon, descending colon, and rectum were collected for later histopathological examination. Due to the macroscopic alterations seen in the colonoscopy and the confirmed laboratory diagnosis of CDI, the clinician proceeded with the FMT.

The donor fecal solution used in the FMT was previously prepared. First, a healthy donor was selected based on previous publications (CHAITMAN et al., 2020; CHAITMAN et al., 2016; REDFERN et al., 2017; PEREIRA et al., 2018). Briefly, a seven-year old dachshund dog without history of gastrointestinal disorder in the last six months and fed commercial dry food was invited to donate. The stool sample of the donor tested negative for all enteropathogens previously described in the present study. Approximately $65 \mathrm{~g}$ of donor's 
feces were diluted in $250 \mathrm{ml}$ of sterilized phosphate buffered saline (REDFERN et al., 2017; PEREIRA et al., 2018) and, after filtration through a sterilized medical gauze pad (SUGITA et al., 2019), were stored in $60 \mathrm{~mL}$ syringes at $-80^{\circ} \mathrm{C}$ until the procedure, which occurred 14 days later. For the FMT, a total of $60 \mathrm{ml}$ of the donor fecal solution was warmed to $36{ }^{\circ} \mathrm{C}$ and administered directly into the ascending colon using the working channel of the endoscope. The animal's pelvis was kept elevated with an orthopedic pillow for 20 minutes to prevent the fluid from escaping. All animal procedures in this study were approved by the Animal Experimentation Ethics Committee of the Universidade Federal de Minas Gerais (protocol number 109/2017).

Later, histopathological analysis of the samples collected via colonoscopy revealed a mild lymphoplasmacytic and neutrophilic colitis, corroborating the macroscopic findings and the laboratorial diagnosis of CDI. As previously planned, the dog returned 15 days after the procedure. The animal was in good condition and had had no diarrheic episodes since the FMT. A new fecal sample was collected and was negative for $\mathrm{A} / \mathrm{B}$ toxins and for $C$. difficile isolation. Six months after the transplantation, the animal was still healthy and without relapse. This result is similar to that previously described by Sugita et al. (SUGITA et al., 2019) which reported the absence $\mathrm{A} / \mathrm{B}$ toxins and $C$. difficile strains in stool samples collected 7, 36 and 124 days after oral FMT in a dog with CDI. Together, these results suggested that the FMT not only successfully treated the diarrhea associated with CDI these two dogs, but it also eliminated $C$. difficile colonization-thus preventing the animal from becoming an asymptomatic carrier of this possible zoonotic pathogen.

In order to better characterize this case, the isolate was submitted to multi-locus sequence typing (MLST) and ribotyping (GRIFFITHS et al., 2010; JANEZIC \& RUPNIK, 2010). The isolate was from ribotype 106 and sequence type 42, which is frequently reported in dogs and is also one of the most prevalent ribotypes implicated in human CDI worldwide (JANEZIC et al., 2014; SILVA et al., 2015; CARLSON et al., 2019). This finding is accordance with other studies, highlighting the possibility of dogs being reservoirs of toxigenic $C$. difficile strains for humans (RODRIGUEZ et al., 2016; STONE et al., 2016).

Due to the possibility of zoonotic disease, the antimicrobial resistance of $C$. difficile isolated from dogs is also a matter of concern. In the last years, strains from dogs resistant to several antimicrobials, including metronidazole, have been reported (ORDEN et al., 2017; ANDRÉS-LASHERAS et al., 2018). The clinical inefficacy of the previous treatments with metronidazole in this dog also raises the possibility of colonization by a resistant strain. Thus, the minimal inhibitory concentrations (MIC) of metronidazole, vancomycin, clindamycin, moxifloxacin, rifampicin, tetracycline, and ciprofloxacin were determined by gradient test with M.I.C. Evaluator ${ }^{\mathrm{TM}}$ strips (M.I.C.E. ${ }^{\mathrm{TM}}$, Oxoid, USA). Interestingly, the isolate was susceptible to metronidazole and vancomycin-drugs of choice for treating CDI in humans - and to moxifloxacin, rifampicin, tetracycline. Conversely, the strain was resistant to clindamycin and ciprofloxacinantimicrobials that are known to increase the risk factors for CDI development (PIRŠ et al., 2013; BANDELJ et al., 2017). This result rules out, at least partially, the hypothesis of recurrence due to infection by a metronidazole resistant strain. Nevertheless, it is important to remember that up to $30 \%$ of human patients with CDI have a recurrence after antimicrobial treatment despite being infected with metronidazolesusceptible strains, showing that the recurrence is more strongly linked to inadequate restoration of the patients' microbiota than the antimicrobial susceptibility of the strain (ASLAM et al., 2005; BORODY et al.,2011).

Previous studies have shown that FMT is effective for the treatment of recurrent CDI in humans in more than $90 \%$ of cases (CAMMAROTA et al., 2014). Although, not fully understood, it is believed that the rapid reestablishment of the microbiota is the main mechanism underlying the effectiveness of FMT in these cases (BORODY et al., 2011; KELLY et al., 2015). In fact, human patients with CDI are known to have a lower bacterial diversity (VAN NOOD et al., 2013). There are few studies on intestinal microbial composition of diarrheic dogs, and none were specifically done on animals with confirmed CDI (NIINA et al., 2019; NIEDERWERDER et al., 2018). Nevertheless, previous studies showed that dogs with chronic diarrhea, which was the case of the dog in the present study, have lower bacterial diversity in their fecal samples compared to healthy dogs (SUCHODOLSKI et al., 2012; MINAMOTO et al., 2014). FMT for treatment of infectious diarrhea deserves more investigation in animals. So far, there is one study involving dogs with parvovirus infection (PEREIRA et al., 2018) and two reports of oral FMT for treatment of CDI-in a dog and in a marmoset (YAMAZAKI et al., 2017; SUGITA et al., 2019), which all showing promising results. Together, these previous studies and the present research suggested that FMT might be a safe and useful tool for the treatment of CDI diarrhea in dogs. Further studies are 
still needed to clarify the benefits of this procedure as well as determine indications and selection criteria for donors and recipients.

\section{ACKNOWLEDGMENTS}

This research was supported by funds from Coordenação de Aperfeiçoamento de Pessoal de Nível Superior (Prêmio CAPES 2015 - 0774/2017), Conselho Nacional de Desenvolvimento Científico e Tecnológico (CNPq - 406402/20183), Fundação de Amparo à Pesquisa do Estado de Minas Gerais (FAPEMIG - APQ-00524-17).

\section{BIOETHICS AND BIOSSECURITY COMMITTEE APPROVAL}

All animal procedures in this study were approved by the institutional ethics committee of Universidade Federal de Minas Gerais (CEUA-UFMG), protocol 109/2017.

\section{DECLARATION OF CONFLICT OF INTERESTS}

The authors declare no conflict of interest. The founding sponsors had no role in the design of the study; in the collection, analyses, or interpretation of data; in the writing of the manuscript, and in the decision to publish the results.

\section{AUTHOR CONTRIBUTIONS}

All authors contributed to the study conception. And read and approved the final manuscript.

\section{REFERENCES}

ANDRÉS-LASHERAS, S. et al. Preliminary studies on isolates of Clostridium difficile from dogs and exotic pets. BMC Veterinary Research, v.14, n.1, p.77, mar. 2018. Available from: $<$ https://doi. org/10.1186/s12917-018-1402-7>. Accessed: Jun. 16, 2020. doi: $10.1186 / \mathrm{s} 12917-018-1402-7$.

ASLAM S., et al. Treatment of Clostridium difficile-associated disease: old therapies and new strategies. The Lancet Infectious Disease, v.5, n.9, p.549-57, sep. 2005. Available from: <https:// doi.org/10.1016/S1473-3099(05)70215-2>. Accessed: Jun. 19, 2020. doi: 10.1016/S1473-3099(05)70215-2.

BANDELJ P., et al. Antimicrobial susceptibility patterns of Clostridium difficile isolates from Family Dairy Farms. Zoonoses and Public Health., v.64, n.3, p.213-221, aug. 2017. Available from: <https://doi.org/10.1111/zph.12299>. Accessed: Jun. 19, 2020. doi: 10.1111/zph. 12299 .

BORODY T. J.; KHORUTS A. Faecal microbiota transplantation and emerging applications. Nature Reviews Gastroenterology \& Hepatology, v9, p.88-96, dec. 2011. Available from: <https:// doi.org/10.1038/nrgastro.2011.244>. Accessed: Jun. 19, 2020. doi: $10.1038 /$ nrgastro.2011.244.

CAMMAROTA G., et al. Fecal microbiota transplantation for the treatment of Clostridium difficile infection: a systematic review. Journal of Clinical Gastroenterology, v.48, n.8, p.693702, sep.2014. Available from: <https://pubmed.ncbi.nlm. nih.gov/24440934/>. Accessed: Jun. 19, 2020. doi: 10.1097/ MCG.0000000000000046

CARLSON T. J., et al. Clostridioides difficile ribotype 106: A systematic review of the antimicrobial susceptibility, genetics, and clinical outcomes of this common worldwide strain. Anaerobe, v.62, 102142, Nov. 2019. Available from: <https://doi. org/10.1016/j.anaerobe.2019.102142>. Accessed: Jun. 19, 2020. doi: $10.1016 /$ j.anaerobe.2019.102142.

CHAITMAN J., et al. Commentary on key aspects of fecal microbiota transplantation in small animal practice. Veterinary Medicine; v.7, p.71-74, May. 2016. Available from: <https://doi. org/10.2147/VMRR.S105238>. Accessed: Jun. 19, 2020. doi: 10.2147/VMRR.S105238.

CHAITMAN J., et al. Fecal Microbial and metabolic Profiles in Dogs with Acute Diarrhea Receiving Either Fecal Microbiota Transplantation or Oral Metronidazole. Frontiers in Veterinary Science. v.7, p.192, Apr 2020. Available from: <https://doi. org/10.3389/fvets.2020.00192>. Accessed: Jun. 19, 2020. doi: 10.3389 /fvets. 2020.00192 .

DE ROO A. C.; REGENBOGEN S. E. Clostridium difficile Infection: an epidemiology Update. Clinics in Colon and Rectal surgery, v.33, n.2, p.49-57, Mar. 2020. Available from: <https:// doi.org/10.1055/s-0040-1701229>. Accessed: Jun. 20, 2020. doi: $10.1055 / \mathrm{s}-0040-1701229$.

DE SANTIS A. C., et al. Estimated prevalence of nematode parasitism among pet cats in the United States. Journal of the American Veterinary Medical Association, v.228, p.885-892, mar. 2006. Available from: <https://doi.org/10.2460/javma.228.6.885>. Accessed: Jun. 19, 2020. doi: 10.2460/javma.228.6.885.

DI XIUZHEN et al. A meta-analysis of metronidazole and vancomycin for the treatment of Clostridium difficile infection, stratified by disease severity. Brazilian Journal of Infectious Diseases, v.19, p.339-349, Aug .2015. Available from: <https:// doi.org/10.1016/j.bjid.2015.03.006>. Accessed: Jun. 19, 2020. doi: 10.1016/j.bjid.2015.03.006.

DINIZ A. N., et al. The incidence of Clostridioides difficile and Clostridium perfringens netF-positive strains in diarrheic dogs. Anaerobe, v.49, p.58-62, Feb. 2018. Available from: $<$ https://doi. org/10.1016/j.anaerobe.2017.12.003>. Accessed: Jun. 19, 2020. doi: 10.1016/j.anaerobe.2017.12.003.

FRANCK S. M., et al. Multiplex PCR for enterotoxigenic, attaching and effacing, and Shiga toxin-producing Escherichia coli strains from calves. Journal of clinical microbiology. v.36, n.6, p.1795-1797, Jun. 1998. Available from: $<$ https://doi.org/10.1128/ jcm.36.6.1795-1797.1998>. Accessed: Jun. 19, 2020. doi: 10.1128/ jcm.36.6.1795-1797.1998.

GOHARI I. M., et al. A novel pore-Forming Toxin in Type A Clostridium perfringens Is Associated with Both Fatal Canine Hemorrhagic Gastroenteritis and Fatal Foal Necrotizing Enterocolitis. PLoS One, v.10, e.0122684, Apr, 2015. Available from: $<$ https://doi. org/10.1371/journal.pone.://doi.org/10.1371/journal.pone.0122684>. Accessed: Jun. 19, 2020. doi: 10.1371/journal.pone.0122684.

GRIFFITHS D. et al. Multilocus sequence typing of Clostridium difficile. Journal of clinical microbiology, v.48, p.770-778, Mar. 
2010. Available from: <https://doi.org/10.1128/JCM.01796-09>. Accessed: Jun. 19, 2020. doi: 10.1128/JCM.01796-09.

GUNZBURG S. T, et al. Identification of enteropathogenic Escherichia coli by PCR-based detection of the bundle-forming pilus gene. Journal of clinical microbiology, v.33, p.13751357. Available from: <https://doi.org/10.1128/JCM.33.5.13751377.1995>. Accessed: Jun. 19, 2020. doi: 10.1128/ JCM.33.5.1375-1377.1995.

JANEZIC S., et al. International Clostridium difficile animal strain collection and large diversity of animal associated strains. BMC Microbiology, v.4, p.173, Jun. 2014. Available from: $<$ https://doi. org/10.1186/1471-2180-14-173>. Accessed: Jun. 19, 2020. doi: $10.1186 / 1471-2180-14-173$.

JANEZIC, S.; RUPNIK, M. Molecular typing methods for Clostridium difficile: pulsed-field gel electrophoresis and PCR ribotyping. In: MULLANY P., ROBERTS A. P. Clostridium difficile. Methods in Molecular Biology, v.646, 2010. Chapter 4, p.55-65.

KELLY C. R., et al. Update on fecal Microbiota Transplantation 2015: Indications, Methodologies, Mechanisms, and Outlook. Gastroenterology, v.149, p.223-237, Jul. 2015. Available from: $<$ https://doi.org/10.1053/j.gastro.2015.05.008>. Accessed: Jun. 19, 2020. doi: 10.1053/j.gastro.2015.05.008.

KEYBURN A. L., et al. NetB, a new toxin that is associated with avian necrotic enteritis caused by Clostridium perfringens. PLoS Pathogens, v.4, n.2, e26, Feb. 2008. Available from: $<$ https://doi org/10.1371/journal.ppat.0040026>. Accessed: Jun. 19, 2020. doi: 10.1371/journal.ppat.0040026

KWANG J., et al. 1996. Use of the polymerase chain reaction for Salmonella detection. Letters in applied microbiology, v.22, p.46-51, Jan. 1996. Available from: <https://doi.org/10.1111/ j.1472-765X.1996.tb01106.x>. Accessed: Jun. 19, 2020. doi: 10.1111/j.1472-765X.1996.tb01106.x.

MARKS S. L., et al. Enteropathogenic bacteria in dogs and cats: diagnosis, epidemiology, treatment, and control. Journal of Veterinary Internal Medicine, v.25, p.1195-1208, Dec. 2011. Available from: $<$ https://doi.org/10.1111/j.1939-1676.2011.00821. $\mathrm{x}>$. Accessed: Jun. 19, 2020. doi: 10.1111/j.19391676.2011.00821.x.

MCDANIELS A .E., et al. Confirmational identification of Escherichia coli, a comparison of genotypic and phenotypic assays for glutamate decarboxylase and Confirmational Identification of Escherichia coli, a Comparison of Genotypic and Phenotypic Assays for Glutamate Decarboxy. Applied and Environmental Microbiology, v.62, p.3350-3354, Sep. 1996. Available from: $<$ https://doi.org/10.1128/AEM.62.9.3350-3354.1996>. Accessed: Jun. 19, 2020. doi: 10.1128/AEM.62.9.3350-3354.1996.

MEER R. R.; J. G. SONGER. Multiplex polymerase chain reaction assay for genotyping Clostridium perfringens. American journal of veterinary research, v.58, p.702-705, jul. 1997.

MINAMOTO Y., et al. Prevalence of Clostridium perfringens, Clostridium perfringens enterotoxin and dysbiosis in fecal samples of dogs with diarrhea. Veterinary Microbiology, v.174 p.463-473, Dec. 2014. Available from: <https://doi.org/10.1016/j. vetmic.2014.10.005>. Accessed: Jun. 19, 2020. doi: 10.1016/j. vetmic. 2014.10.005
NIEDERWERDER M. C. Fecal microbiota transplantation as a tool to treat and reduce susceptibility to disease in animals. Veterinary immunology and immunopathology, v.206, p.65-72, Dec. 2018. Available from: <https://doi.org/10.1016/j. vetimm.2018.11.002>. Accessed: Jun. 19, 2020. doi: 10.1016/j. vetimm.2018.11.002.

NIINA A., et al. Improvement in clinical Symptoms and Fecal Microbiome After Fecal Microbiota Transplantation in a Dog with Inflammatory Bowel Disease. Veterinary Medicine, v.10, p.197-201, Dec. 2019. Available from: <https://doi.org/10.2147/ VMRR.S230862>. Accessed: Jun. 19, 2020. doi: 10.2147/VMRR. S230862.

ORDEN C., et al. Isolation of Clostridium difficile from dogs with digestive disorders, including stable metronidazole-resistant strains. Anaerobe, v.43, p.78-81, Feb. 2017. Available from: $<$ https://doi.org/10.1016/j.anaerobe.2016.12.008>. Accessed: Jun. 19, 2020. doi: 10.1016/j.anaerobe.2016.12.008.

PEREIRA, G. Q. et al. Fecal microbiota transplantation in puppies with canine parvovirus infection. Journal of Veterinary Internal Medicine, v.32, n.2, p.707-711, Mar. 2018. Available from: $<$ https://doi.org/10.1111/jvim.15072>. Accessed: Jun. 19, 2020. doi: 10.1111 jvim. 15072 .

PIRŠ T., et al. Antimicrobial susceptibility of animal and human isolates of Clostridium difficile by broth microdilution. Journal of medical microbiology, v.62, p.1478-1485, Sep. 2013. Available from: <https://doi.org/10.1099/jmm.0.058875-0>. Accessed: Jun. 19, 2020. doi: 10.1099/jmm.0.058875-0.

REDFERN A. et al. Role of the gastrointestinal microbiota in small animal health and disease. Veterinary Record, v.181, p.370, Sep. 2017. Available from: <https://doi.org/10.1136/vr.103826>. Accessed: Jun. 19, 2020. doi: 10.1136/vr.103826.

RODRIGUEZ C., et al. Clostridium difficile in Food and Animals: A Comprehensive Review. Adv Exp Med Biol, v.932, p.65-92, Jun. 2016. Available from: <https://doi.org/10.1007/5584_2016_27>. Accessed: Jun. 23, 2020. doi: 10.1007/5584_2016 27.

SILVA R. O. S, et al. Detection of enterotoxin A and cytotoxin $\mathrm{B}$, and isolation of Clostridium difficile in piglets in Minas Gerais, Brazil. Ciência Rural, v.41, p.1130-1135, Aug. 2011. Available from: <http://dx.doi.org/10.1590/S010384782011005000100>. Accessed: Jun. 21, 2020. doi: 10.1590/ S0103-84782011005000100.

SILVA R. O. S., et al. Clostridioides difficile infection in dogs with chronic-recurring diarrhea responsive to dietary changes. Anaerobe, v.51, p.50-53, Apr. 2018. Available from: $<$ https://doi. org/10.1016/j.anaerobe.2018.03.011>. Accessed: Jun. 19, 2020. doi: 10.1016/j.anaerobe.2018.03.011.

SILVA R. O. S., et al. Clostridium difficile ribotypes in humans and animals in Brazil. Memórias do Instituto Oswaldo Cruz, v.110, n.8, p.1062-1065, Dec. 2015. Available from: <https://doi. org/10.1590/0074-02760150294>. Accessed: Jun. 19, 2020. doi: 10.1590/0074-02760150294.

SILVA R. O. S., et al. Detection of A/B toxin and isolation of Clostridium difficile and Clostridium perfringens from foals. Equine Veterinary Journal. 45, p.671-675, Nov, 2013. Available from: <https://doi.org/10.1111/evj.12046>. Accessed: Jun. 19, 2020. doi: $10.1111 /$ evj.12046. 
SILVA, R. O. S., et al. Clostridium perfringens and C. difficile in parvovirus-positive dogs. Anaerobe, v.48, p.66-69, 2017. Available from: <https://pubmed.ncbi.nlm.nih.gov/28733230/>. Accessed: Sep. 14, 2020. doi: 10.1016/j.anaerobe.2017.07.001.

STONE N. E., et al. More than $50 \%$ of Clostridium difficile Isolates from Pet Dogs in Flagstaff, USA, Carry Toxigenic Genotypes. PLoS One, v.11, e0164504, Oct. 2016. Available from: <https:// doi.org/10.1371/journal.pone.0164504>. Accessed: Jun. 19, 2020. doi: 10.1371/journal.pone.0164504.

SUCHODOLSKI J. S., et al. The fecal microbiome in dogs with acute diarrhea and idiopathic inflammatory bowel disease. PLoS One, v.7, n.12, e51907, Dec. 2012. Available from: $<$ https://doi. org/10.1371/journal.pone.0051907>. Accessed: Jun. 19, 2020. doi: 10.1371/journal.pone.0051907.

SUGITA K., et al. Oral faecal microbiota transplantation for the treatment of Clostridium difficile-associated diarrhoea in a dog: a case report BMC Veterinary Research, v.15, p.11, Jan. 2019. Available from: <https://doi.org/10.1186/s12917-018-1754-z>. Accessed: Jun. 19, 2020. doi: 10.1186/s12917-018-1754-z.

TOKUDA, K. Characterization of typical and atypical enteroaggregative Escherichia coli in Kagoshima, Japan: Biofilm formation and acid resistance. Microbiology and Immunology, v.54. p.320-329, Jun. 2010. Available from: <https://doi.org/10. $1111 /$ j.1348-0421.2010.00210.x>. Accessed: Jun. 19, 2020. doi: 10.1111/j.1348-0421.2010.00210.x.
VAN NOOD E., et al. Duodenal infusion of donor feces for recurrent Clostridium difficile. The New England journal of medicine, v.368, p.407-415, Jan. 2013. Available from: <https:// doi.org/10.1056/NEJMoa1205037>. Accessed: Jun. 19, 2020. doi: 10.1056/NEJMoa1205037.

WEESE, J. S. Clostridium (Clostridioides) difficile in animals. Journal of Veterinary Diagnostic Investigation, v.32, n.2, Jan. 2020. Available from: <https://doi.org/10.1177/1040638719899081>. Accessed: Jul. 23, 2020. doi: 10.1177/1040638719899081.

YAMAMOTO T.; NAKAZAWA M. Detection and sequences of the enteroaggregative Escherichia coli heat-stable enterotoxin 1 gene in enterotoxigenic $E$. coli strains isolated from piglets and calves with diarrhea. Journal of Clinical Microbiology, v.35, n.1, p.223-227, Jan. 1997. Available from: <https://doi.org/10.1128/ JCM.35.1.223-227.1997>. Accessed: Jun. 19, 2020. doi: 10.1128/ JCM.35.1.223-227.1997.

YAMAZAKI Y., et al. Faecal transplantation for the treatment of Clostridium difficile infection in a marmoset. BMC Veterinary Research v.13. p.150, May. 2017. Available from: <https://doi. org/10.1186/s12917-017-1070-z>. Accessed: Jun. 20, 2020. doi: 10.1186/s12917-017-1070-z.

WETTERWIK, K. et al. Clostridium difficile in faeces from healthy dogs and dogs with diarrhea. Acta Vet Scand. v.55, p.23, 2013. Available from: <https://pubmed.ncbi.nlm.nih.gov/23497714/>. Accessed: Jun. 20, 2020. doi: 10.1186/1751-0147-55-23. 